\author{
Isidora JARIĆ iD \\ University of Belgrade \\ dorajar@eunet.rs
}

\title{
THE UNIVERSITY AND ITS ROLE IN THE PROCESS OF EUROPEAN INTEGRATIONS
}

\section{THE DYSTOPIAN FAIRY TALE OF SERBIAN UNIVERSITY}

ABSTRACT The paper discusses the contemporary social role of the university in the three referent contexts: (a) the wider global context, (b) the regional context of European integrations, and (c) the local context of Serbian Society. The analysis discusses challenges of global context and university transformation, initial ideas of the Bologna process and the main directions of its implementation, and contemporary political and social challenges with the relationship between the university and its referent social environment and the value concepts shaping that relation. The latest tendencies of the abandonment of the university from its civil mission (Ćulum and Ledić, 2011) as one of the fundamental value concepts of modern universities has led to new escapist strategy that breaks the links between the university and the social environment in an almost artificial way. The paper discuss this tendency on the example of Serbian society and its university system, showing that the Serbian project of European integration has reached the point where it is necessary to articulate future directions of development so that they do not spontaneously take on malignant forms. On the one hand, breaking the link between the university and community jeopardizes the survival of the university as we know it, and on the other hand, it eliminates serious social dialogue on the directions of future development.

Key words: University, civil mission, European integrations 
Once upon a time the evil fairy Maleficent, who was angry curses the princess proclaiming Aurora will grow in grace and beauty, but before the sun sets on her sixteenth birthday, she will prick her finger on the spindle of a spinning wheel and die. Merryweather uses her magic to weaken the curse; instead of dying, Aurora will fall into a deep slumber, only broken by true love's kiss.

(Sleeping Beauty)

Maleficent appears and lures Aurora into a dark tower and tricks her into touching the spindle of a cursed spinning wheel. Aurora pricks her finger, fulfilling the curse only moments before the sun sets. The three fairies place the sleeping Aurora on a bed in the highest tower and cast a powerful spell on everyone in the kingdom, causing them to sleep until the spell on their princess is broken. Like a sleeping princess, the University of Belgrade, the largest and the oldest university in Serbia and the Western Balkans, was during the next few months awakened from its deep (ethical) slumber.

The university as an institution has passed through and is still passing through a turbulent transformation initiated by external (global, regional and local) societal and cultural changes and their mutual interactions. The intensity of these external transformations has multiplied the challenges the university needs to respond to. In the following text we will point to the major of those challenges, from global to local, respectively.

\section{CHALLENGES OF GLOBAL CONTEXT AND UNIVERSITY TRANSFORMATION}

In his now classic text "Problems in the Transition from Elite to Mass Higher Education" from $1974^{1}$ and a more recent text from 2005, "Reflections on the Transition from Elite to Mass to Universal Access: Forms and Phases of Higher Education in Modern Societies since WWII", Martin Trow sketches the major global coordinates ${ }^{3}$ of this process over a historical period spanning decades. In these works, he distinguishes between three different types of universities in terms of coverage of the expected percentage of the population (age cohorts of those in higher education student age) that these ideal-type university models want and/or need to include as students in the

$1 \quad$ M. Trow, "Problems in the Transition from Elite to Mass Higher Education", in Policies for Higher Education, Paris 1974.

2 Idem, "Reflections on the Transition from Elite to Mass to Universal Access: Forms and Phases of Higher Education in Modern Societies since WWII", University of California, Berkeley, Institute of Governmental Studies, 2005, at <http://escholarship.org/uc/item/96p3s213\#page-5>.

3 According to Peter Scott, even today Trow's triptych continues to provide the most compelling explanatory framework available to policy makers, institutional leaders and researchers (P. Scott, "Martin Trow's Elite-Mass-Universal Triptych: Conceptualising Higher Education Development", Higher Education Quarterly, vol. 73, no. 4 (2019)). 
higher education system. In this sense, he distinguishes three types of universities: elite, mass, and universal. In his view, these three ideal types of higher education systems have historically been successively replaced, growing from the first to the second and third types. Historically, most industrialized countries have progressively moved from an elite to a universal higher education system over the last $40-50$ years, seeking to adapt to the intense changes in society, economy and technology. Trow believes that the structure of higher education institutions is in some way relational to the (broader and narrower) social context(s) within which they are constituted and exist, and that the way in which institutional curricula and dominant approaches to teaching and research are structured is in direct relation with social needs and development priorities derived from the same social context(s). Thus, in its interpretation, the social context itself influences the formation of a particular type of university and higher education system, but also the university, by its activity, (re)shapes that context. With this in mind, Trow also includes in his conceptualization of these ideal types the consideration of possible social and structural "missions" of the university, seeking to once again emphasize the two-way nature of the relationship between a university and the social environment/ society within which that university operates.

The Elite University. The basic social mission of this university is to educate the social elite, which is also reflected through the elements of its curriculum. This type of university is based on the idea that university education aims to "shape the mind and character" of students through distinctly structured concepts of academic and professional knowledge. The higher education institutions within these universities themselves are relatively small and homogeneous, with clearly delimited boundaries separating the academic community from the rest of society. These universities include up to $15 \%$ of the student-age cohort in the higher education process. ${ }^{4}$ This "elitist" concept of university education implies that it should only be accessible to the "best and brightest".

The Mass University. The basic social mission of this university is to transfer knowledge and prepare the student population for various leadership roles and positions, above all those that contribute to the country's economic development. In a sociostructural sense, it is more open, but still only to those with appropriate pre-university educational attainment. The structure of the curriculum is transformed into a modular one, and it becomes much more flexible, yet standardized. The boundaries between academia and the rest of society are becoming blurred and permeable, and the number of students is growing significantly, so that these universities manage to cover as much as $16-50 \%$ of the student-age cohort within the general population in higher education. ${ }^{5}$ The basic idea behind this type of university is the "massing up" of higher education, which becomes the most open channel of vertical social mobility, which in turn has the effect of reshaping the social structure and adapting it to the projected developmental priorities of society.

M. Trow, "Reflections on the Transition..."

Ibid. 
The Universal University. Its projected social mission is to participate in preparing the entire population to take part in intensifying social and technological changes. The boundaries between formally structured knowledge and practices of everyday life within the curriculum are beginning to deconstruct and collapse, as are the boundaries between educational institutions and other aspects of life, including the workplace. The academic community as such is also undergoing a process of deconstruction, and the coverage of the student-age cohort in higher education ranges between $51-100 \%{ }^{6}$ It is this fragmentation of educational experiences and the defragmentation of knowledge itself that are becoming the main features of contemporary universities.

In addition, all contemporary universities and higher education as a whole face a series of new problems that are a characteristic product of this particular moment in time. Trow $^{7}$ highlights the six most significant problems emerging from global transformational change. Among these he includes:

1. The impact of new information technologies on traditional forms of higher education. This impact is potentially very destabilizing for the higher education system as it decomposes it internally, making some traditional forms of higher education practice such as live teaching replaceable (through e.g. distance learning), which further raises the question of the necessity of a university's geographical location, for example.

2. The rising costs of higher education facing fiscal stagnation. The number of students is steadily increasing, while state financial support to universities remains the same, potentially resulting in a decline in the quality of teaching and scientific research.

3. Problems arising from the creation and adaptation of the governing structure of elite research universities to mass education institutions.

4. Declining levels of the cultural knowledge, general education, and literacy of students entering the higher education system. Trow refers to the "new postlinear" generation, ${ }^{8}$ which has been exposed to video and audio cultural content since its earliest childhood, resulting in decreased reading ability.

5. Intensification of international industrial competition under the influence of a pervasive globalization process. With regards to the university, this refracts through (a) the commercialization of research and teaching, which emerges as a consequence of the acceleration stemming from the development of new technologies, (b) the relocation of teaching and research outside the university occurs as a short-term consequence, and (c) the problem of maintaining the integrity and autonomy of the university as a long-term consequence.

6. Changes in academic culture. In some countries, there has been a marked decline

Ibid.

M. Trow, "From Mass Higher Education to Universal Access: The American Advantage", University of California, Berkeley Research and Occasional Paper Series, CSHE.1.00 (2000), at <https://cshe. berkeley.edu/sites/default/files/publications/2000_from_mass_higher_education_to_universal_ access_the_american_advantage.pdf $>$.

8 Ibid. 
in morale among members of the academic community, as well as the deprofessionalization of university professors and lecturers. All this is accompanied by a loss of academic solidarity and a loss of perception of the university as a community. ${ }^{9}$

All this significantly changes the position and the perceived role of the university, forcing the university as an institution to take on these changes and adapt its own institutional, legal and customary procedures to the changed coordinates of the global landscape of everyday reality.

\section{REGIONAL EUROPEAN CONTEXT: THE BOLOGNA REFORM}

Within this significantly changed global context, a no less intense process is underway to establish a single European higher education space and to standardize it, ${ }^{10}$ which is a precondition for transforming existing universities and higher education institutions within them into what Trow terms the universal university.

This process formally began with the signing of the Sorbonne Declaration, ${ }^{11}$ signed by the Ministers of Education of France, Germany, the United Kingdom and Italy in May 1998. This document proposes the creation of a single framework for European higher education in order to facilitate the nostrification of studies/diplomas, in order to provide the preconditions for the future mobility of teachers, students and the workforce within the wider European area. Although this legal document took the form of a statement of intent rather than a legally binding statement, the following year at a meeting of European ministers of education in Bologna, ${ }^{12}$ an agreement was reached on the beginning of what we today call the "Bologna Process". In this sense, this meeting represents a symbolic turning point and the beginning of a new chapter in the history of European university life. The Bologna Process, derived from the Sorbonne Declaration, has been accepted in the European region, without much debate or resistance. In the new European university and socio-political context, the legal framework of the Bologna Process is understood, both within public and political discourse, as general and binding. This framework establishes the coordinates of the new desired European higher education system, which equates to the automatic abolition of a large number of national-state competencies. Perhaps this is the reason why a relatively easy political consensus was established..$^{13}$ The so-called Bologna process is one of the most disputed and one of the most influential long-term policy changes the European Union has ever succeeded

9 Ibid.

10 In terms of ensuring comparability of different educational degrees and higher education qualifications within and between different national higher education systems.

11 <http://www.ehea.info/media.ehea.info/file/1998_Sorbonne/61/2/1998_Sorbonne_Declaration_ English_552612.pdf $>$.

12 <http://www.magna-charta.org/resources/files/BOLOGNA_DECLARATION.pdf>.

13 K.P. Liessmann, Teorija neobrazovanosti. Zablude drustva znanja, transl. by S. Muhamedagic, Zagreb 2008, p. 89. 
to start. ${ }^{14}$ This is most likely because the Bologna reform succeeded in thematizing in the field of higher education which, at the level of political aspirations for unity, has suffered a painful political failure in the political reality of the European continent. The effect of the driving force behind the new integration and enlargement processes, which emerged as a possibility at the very beginning of this process, should not be overlooked, given that many countries still awaiting EU membership, such as Serbia, have joined the Bologna Process, but also others that are not even located on the European continent. ${ }^{15}$ In its final implementation, this process should have resulted in the establishment of a single European higher education area that would allow comparability of different educational levels and higher education qualifications, and consequently the mobility of researchers-teachers and students.

However, despite the initial absence of resistance, most likely caused by enthusiasm for the fantasy of expanding the European space and the geographical and professional mobility of its inhabitants with the first attempts to implement the Bologna reform, problems arose from the way it was operationalized. The operationalization of this process was entrusted to the nation-states, their educational systems and universities, in that order, and the coordination of politically constructed supranational bodies tasked with monitoring and evaluating the implemented reform efforts at national and regional levels. ${ }^{16}$

Great expectations and fantasies related to the Bologna reform of higher education have suffered from much criticism during the collision with the real problems of its implementation of the field. The result was that the Bologna process, which started as an intergovernmental initiative, was transformed by the actions of the European Commission, ${ }^{17}$ as a normative attempt to define appropriate operational logics for $\mathrm{Eu}-$ ropean universities ${ }^{18}$ into a process whose success depends on the innovation and determination of the supervisor, not of those implementing it. The lack of positive motivation in the global long-lasting pattern of inequality in power, wealth and cultural influence ${ }^{19}$ within the European continent resulted in relatively unstable commitment of the national states situated on the symbolic periphery of the imagined European space to the implementation of the Bologna reform.

14 C. Dienel, "Bologna - a Utopy of Harmony for European Higher Education", Innovation. The European Journal of Social Science Research, vol. 32, no. 4 (2019), p. 403.

15 By 2019, 48 states have joined the European Higher Education Area (EHEA). Ibid.

16 http://www.ond.vlaanderen.be/hogeronderwijs/bologna/documents/WGR2007/bologna_process_ in_global_setting_finalreport.pdf.

17 Because the problems with implementation of Bologna reform on the level of national states were occurring frequently, and because of the dilatations of the initial reform ideas and goals, the European Commission came to act more and more as an active agenda setter and promoter of its policy preferences (E.M. Vögtle, "20 years of Bologna - A Story of Success, a Story of Failure", Innovation. The European Journal of Social Science Research, vol. 32, no. 4 (2019)) in order to support the process and direct its major trends. Ibid.

19 R. Connell, Southern Theory. The Global Dynamics of Knowledge in Social Science, Cambridge 2015, p. 212. 


\section{LOCAL CONTEXT: THE CASE OF SERBIA}

Serbia is a country geographically located in southeast Europe and geopolitically outside of the main European political flows. The series of military conflicts and the transformation from socialism to capitalism that started in the 1990s reshaped the state borders, socio-political organization and mental geography of the domicile population. This turbulent societal shift opened numerous fissures in the political tissue which become a home for different micro initiatives trying to compensate for the lack of functional citizen-friendly social regulation within various parts of the societal system. Even though the political and social life of Serbian society has been shaped for almost two decades by the narrative of European integration, ${ }^{20}$ Serbia is still far away from realization of that goal.

In the area of higher education one of the main aims has been to increase the comparability and compatibility of Serbian higher education system with European higher education structures with regards to quality and outcomes. Serbian universities entered the process of institutional and curricula adjustment in 2003, when Serbia joined the Bologna Process. Since then the Serbian higher education system has passed through series of transformations supported by multiple amendments to the Law on Higher Education (in 2005, 2007, 2008, 2010, 2012, 2013, 2014, 2015, 2016, 2017, 2018 and 2019). ${ }^{21}$ However, many of these changes did not apply in the same manner to all aspects of the higher education system. It seems, at least according to recent affairs, that some of the private universities interpret the Bologna rules more freely.

The case of the false doctoral degree of the Rector of the private Megatrend University, Mica Jovanovic, as well as the suspicious doctorate of the Minister of the Interior of the Republic of Serbia, still Dr. Nebojsa Stefanovic, whose mentor was Jovanovic, also a member of the Commission for Doctoral Dissertation Defense, which shook the Serbian public in 2014, testifies to the new practices in one segment of the Serbian academic community. In April 2014, the then candidate for Prime Minister of Serbia, and the current President of Serbia, Aleksandar Vucic, announced reform of the education system, mentioning that many young people were leaving Serbia because of the collapsed education system. ${ }^{22}$ Shortly after, a group of researchers published the results of the analysis of the doctoral theses of several politicians, with special reference to the

20 Whatever the political or social actors choose in their narratives for the path of closer integration of Serbia into the European space, or actively oppose it, it becomes one of the inevitable toponyms of all public discussions on a wide variety of topics.

21 Since 2003 the Serbian government has adopted two different Laws on Higher Education (in 2005 and 2017) and many authentic interpretations for the Law on Higher Education (Sl. glasnik $R S$, No 76/2005) - authentic interpretations published in Sl. glasnik RS No. 100/2007, 97/2008, 44/2010, 93/2012, 89/2013, 99/2014, 45/2015, 68/2015 and 87/2016, and for the Law on Higher Education (Sl. glasnik RS No 88/2017), authentic interpretations published in Sl. glasnik RS No. 27/2018, 73/ 2018 and 67/2019.

22 Z. Šuvaković, “Serbia’s Degree Mills”, Al Jazeera Opinion, 25 July 2014, At <https://www.aljazeera. com/indepth/opinion/2014/07/serbia-degree-mills-2014725133314619696.html>. 
work of Minister of the Interior, Nebojsa Stefanovic. ${ }^{23}$ The analysis indicates that the author not only freely plagiarized parts of other people's work without citing sources, but also that this work does not satisfy some of the elementary assumptions of serious scientific work: The entire doctoral thesis is actually descriptive in nature, with an eclectic fusion of various descriptions that neither provide a meaningful whole nor contain research value. The author does not state how the hypotheses came to be, why they are important, nor does he carry out their checks and valid analyses. Some of the 'bypotheses' are pure tautologies (for example, 'more efficient local government $=$ more economical in operation'). ${ }^{24}$

The doctorate of Stefanovic, the interior minister and one of the closest associates of the President of Serbia, as well as that of his mentor, the owner of the university at which he received his education, have become the subject of news in the media worldwide, ${ }^{25}$ including commentary from some of the most famous and influential magazines dealing with education and science, such as the Times Higher Education Supplement. ${ }^{26}$ In addition to Stefanovic, Grove states that the popular former water polo player and current politician Aleksandar Sapic allegedly copied one-third of his doctoral thesis from the book Selling and Sales Management by David Jobber and Geoffrey Lancaster, published in $1997 . .^{27}$

In conclusion, the authors of the analysis of Stefanovic's "doctorate" state: A person who is willing to 'pursue' as a doctorate a scientifically worthless work that does not meet the minimum criteria is not fit to perform a public function. Accession to the European Union is a strategic priority of the Serbian Government. Let's look up to European examples. Anet Schawan, a former German federal education minister, had to resign in February 2013 after it was proved she had plagiarized her doctorate. The same fate was experienced in 2011 by Karl-Theodorzu Gutenberg, the then German Minister of Defense and the closest associate of Chancellor Angela Merkel. In Hungary, a similar case happened with former President Pal Schmitt in 2010. In his exposition to the National Assembly, Prime Minister Aleksandar Vucic stated that it is worrying that "educated staff who remain [in Serbia] largely have diplomas of dubious quality due to the collapsed education system." Here is an opportunity for the Prime Minister and other competent institutions to react, and to support the words with deeds. ${ }^{28}$

Unfortunately, this decline in morale is not limited by the imaginary boundaries of the university's academic environment. The evidence is the affair related to the false

23 U. Grušić, B. Radeljić, S. Tomić, "Kako do doktorata? Lako! Slučaj ministra Stefanovića”, Peščanik, 1 June 2014, at <https://pescanik.net/kako-do-doktorata-lako-slucaj-ministra-stefanovica/>.

24 Ibid.

25 M. Robinson, “The Minister, His Mentor and the Fight against a Suspect System in Serbia”, Reuters, 23 June 2014, at <https://uk.reuters.com/article/uk-serbia-education-fraud/the-minister-his-mentor-and-the-fight-against-a-suspect-system-in-serbia-idUKKBN0EY1EV20140623>.

26 J. Grove, "Serbian Political Figures Accused of plagiarising their PhDs", Times Higher Education Supplement, 24 July 2014, at <https://www.timeshighereducation.com/news/serbian-political-figures-accused-of-plagiarising-their-phds/2014668.article>.

27 Ibid.

28 U. Grušić, B. Radeljić, S. Tomić, "Kako do doktorata?..." 
representation of the current MP of the Socialist Party of Serbia in the Parliament of the Republic of Serbia, member of the Committee on Economy, Regional Development, Trade, Tourism and Energy, and member of the Committee on Spatial Planning, Transport, Infrastructure and Telecommunications, Dr. Novica Toncev, who was found not to have a doctoral degree. Toncev himself did not deny these allegations, but he explained this act of impersonation by the fact that there is no abbreviation for what he is - a doctoral candidate. ${ }^{29}$ Further comment seems redundant.

However, since 2014 the virus of faux diploma affairs has also spread to state universities. The most serious and media-covered case is the plagiarized doctorate of the then-mayor of Belgrade and the current Minister of Economy, Sinisa Mali, ${ }^{30}$ which was defended at the Faculty of Organizational Sciences, University of Belgrade. This case was opened in 2014 by Rasa Karapandza, a professor at the European School of Business in Germany, by publishing the text "Great Secrets of a Little ${ }^{31}$ Master - Or How Sinisa Mali Stole a Ph.D", on the platform Peščanik. Linking the oldest and largest university in Serbia to the granting of a doctoral degree to a candidate who is a potential plagiarist has upset the academic public, who in this case continued to seek prosecution despite various political pressures. Unfortunately, for many reasons, including those of a formal nature, ${ }^{32}$ the dormant university has for a long time failed to address this challenge in an effective and competent manner. However, in September 2019, a group of social actors,

29 Daily newspaper Blic, 26 July 2014, p. 10.

30 Some specific examples of plagiarism by Mali are listed in "Belgrade Mayor Sinisa 'Little' Mali is a Big-Time Plagiarist”, Balkanist, 9 July 2014, at <https://balkanist.net/belgrade-mayor-sinisa-little-big-plagiarist/>.

31 This is wordplay: the English translation of the surname Mali is Little.

32 Such as the legal codification of plagiarism and the formation of bodies competent to determine possible non-academic conduct, ethics committees. Namely, during the case of Mali on July 10, 2016, the University of Belgrade adopted the Code of Professional Ethics. With this legal act entering into force on July 22, 2016, for the first time in the history of the University of Belgrade, legal practices of academic dishonesty such as plagiarism, have been legally codified (Article 22 of this Code) and the bodies responsible for ascertaining those practices have been designated. However false and undeserved diplomas are just one of the challenges facing the higher education system in Serbia, as reported by experts from the European Commission in 2018, who have made a series of remarks in their analysis of the work of the Accreditation and Quality Review Commission (KAPK). These remarks relate to: insufficiently clear provisions that allow members of the Serbian Accreditation and Quality Control Commission to work at the same time in the bodies whose activity this Commission is supposed to evaluate; dependence of the Commission on the Government (lack of own accounts, unclear financial situation, etc.); but above all insufficient independence when it comes to evaluating projects in Serbia (ENQA Agency Review: Commission on Accreditation and Quality Assurance (CAQA), Brussels, 22 February 2018, pp. 51-52). When this commission recently determined that there were as many as 103 "controversial" doctoral degrees issued by higher education institutions in Serbia, this prompted Minister of Education, Science and Technological Development Sarcevic to argue that this was the reason Serbia was put "under scrutiny" by the European Commission. However, if one reads the report of European Commission experts, it is clear that there are a number of contentious issues that have not been adequately resolved since the previous evaluation, 2012, so one could look there for reasons for the "increased surveillance" of the Serbian education system, which has recently been sinking in its own inertia of passive adaptation. 
members of the academic community (supported by the major oppositional prodemocratic political parties and independent university professors), lost patience and blocked the Rectorate Building, wanting to pressure the university and the academic community to complete the initiated and blocked review process of Sinisa Mali. This "eager group" of members of the academic community consisted of students. It is not surprising that it is they, as part of the academic community with the least power, who first articulated the carcinogenic potential of the Mali affair and the long-term damage that would also affect the reputations of their diplomas they have yet to acquire. This selfless act of love of those whom the academic community incorporated into its body only in the 1970s, ${ }^{33}$ students, has awakened their university, breaking the spell and alerting their professors and the academic community. This act reminded the university of the consequences of non-academic practices of particular individuals for the entire academic community and the higher education system in Serbia. This produced within the academic community, on the one side, the articulation of significant civil resistance ${ }^{34}$ against the politics of the government and ruling Serbian Progressive Party and its attempts to jeopardize the university's autonomy, and on the other side, a reaffirmation of the idea of the importance of the civil mission of the university ${ }^{35}$. This case received an epilogue in November 2019, when the Senate of the University of Belgrade, after a number of fantastic twists in the plot, made a unanimous decision to "cancel the doctoral dissertation of Sinisa Mali due to the fact that he had plagiarized his doctorate". ${ }^{36}$

\section{DYSTOPIAN TWIST AND FAIRY TALE LESSONS}

The spirit of the medieval structure of the university in synergy with the promotion mechanisms of the early capitalist guilds has driven universities to stay captive in a time capsule devoid of any historicity. However, materialization of this structural drive in everyday reality in intensive transformation comes with costs: (a) on one side, the loss of contact with everyday life that limits the ability of the academic community to participate in the creation and implementation of future development trajectories, and the alienation of the academia from the wider community/people, (b) on the other side, an

33 J. Enders, "Between State Control and Academic Capitalism: A Comparative Perspective on Academic Staff in Europe", in idem (ed.), Academic Staff in Europe. Changing Contexts and Conditions, London 2001, p. 6.

34 For more than a year, the Faculty of Philosophy, University of Belgrade, which is the oldest faculty within the University of Belgrade and one of the largest, has hosted a panel every Thursday called $I t$ is Not Philosophical to Stay Silent as part of the active support for civil protests that have been taking place in Belgrade every Saturday.

35 "The concept of the university's civil mission articulates a system of values and principles that directs the core activities of the university and the various advocacy activities of university teachers and students in the community, that contribute to the education of socially responsible and active citizens, the development of civil society, democracy and the improvement of quality of life in the community." (B. Ćulum, J. Ledić, Sveučilišni nastavnici i civilna misija sveučilišta, Rijeka 2011, p. 53).

36 “Belgrade Unanimously Annulled Sinisa Mali’s Doctorate”, Blic, 12 December 2019. 
alienated academia is unable to "serve as a medium for addressing the disturbing problems of our time" ${ }^{37}$ and to fulfill its main societal tasks: both perpetuation of the status quo and its antithesis, the preparation for change, are integral aspects of its ethos. Recently, this intrinsic calling appears to have been altered. Relativistic postmodernism and especially the political correctness retort are felt to be moving against the historical foundation and raison d'etre of university life. ${ }^{38}$

This relativistic excuse formulated in the ahistorical time of the universal university provokes the reaction of non-university political actors who give necessary support at the right moment to the part of the academic community that has the strongest connection with the concrete historical moment and the need for instant social intervention. Despite the utopian logic of a fairytale structure in which students save the university that they truly love, in the contemporary reality of Serbian society, Maleficent plays a major role. Politics tried to interfere and impeded the autoregulatory process of evaluation of suspected doctorates. This interference provoked a civic/student initiative, supported by different social actors from outside the university community. This unexpected twist shows that the community cares and needs the university and vice ver$s a$. The heroic narrative of a fairy tale is a plot of a dream from a university's deep slumber interrupted by a blockade. In that dream, the university sees the students as a transformative force that possesses the capacity to change the world. In everyday life these students struggle for survival, have no time to read, and often do not have the capacity to imagine a different world. They are isolated among other powerless actors that cannot contribute to or perform societal change. The support of other social actors (critical public, politicians and professors) has, however, been empowering, giving them the necessary confidence and strength to rouse the hibernating internal institutional, intellectual and organizational capacities necessary for problem solving.

This dystopian fairy tale has two lessons to teach: The first lesson is about our human potential for adjustment to external circumstances, both on individual and institutional levels, and our capacities to control the direction of that transformation. Our ability to adjust and accept anything is one of the greatest dangers we face. Creatures capable of any form of perfect adjustment cannot have strong ethics. ${ }^{39}$

Paradoxically, however, this fairy tale shows that the only way to control the direction of the university transformation is the persistent insistence on specific ethical principles of academic activity, because: Higher education is a moral and political enterprise [my emphasis - I.J.] that must struggle against all forms of dogmatism [...] and provide a vision of the future in which students can function as informed, critical citizens capable of actively participating, shaping, and governing a world..$^{40}$

37 D. Wilkinson, "Transforming the Social Order: The Role of the University in Social Change", Sociological Forum, vol. 9, no. 3 (1994), p. 326.

38 Ibid., p. 329.

39 S. Lem, His Master's Voice, transl. by M. Kandel, Kindle Edition, 2020.

40 H. Giraoux, The University in Chains: Confronting the Military-Industrial-Academic Complex, Boulder, CO 2007, p. 203. 
The second lesson is about the social responsibility of the university toward the community and its mutual relationship. The fairy tale shows that the university seeks interaction with community and needs its corrective potential. If Trow is right, then the loss of a clear boundary between academia and society, in the case of a universal university, should be considered and incorporated into future institutional strategies of university development. One possible way is to involve interested non-university stakeholders in university affairs and vice versa, the University in the affairs of the highest importance for the state, such as the European integration and association project.

Because 'the idea' of the university is only an idea, or an imagined state of affairs ${ }^{41}$ and it is up to us to fulfill it with the appropriate content.

\section{BIBLIOGRAPHY}

"Belgrade Mayor Sinisa 'Little' Mali is a Big-Time Plagiarist", Balkanist, 9 July 2014, at <https://balkanist.net/belgrade-mayor-sinisa-little-big-plagiarist/>.

Chng H.H., "The Idea of the University: National Asset or Ivory Tower??, in A. Heijnen, R. van der Vaart (eds.), Places of Engagement. Reflections on Higher Education in 2040 - A Global Approach, Amsterdam 2018, https://doi.org/10.1515/9789048543656-020.

Connell R., Southern Theory. The Global Dynamics of Knowledge in Social Science, Cambridge 2015.

Ćulum B., Ledić J., Sveučiliš̌ni nastavnici i civilna misija sveučilišsta, Rijeka 2011.

Dienel C., "Bologna - a Utopy of Harmony for European Higher Education", Innovation. The European Journal of Social Science Research, vol. 32, no. 4 (2019), https://doi.org/10.1080/ 13511610.2019.1674131.

Enders J., "Between State Control and Academic Capitalism: A Comparative Perspective on Academic Staff in Europe", in idem (ed.), Academic Staff in Europe. Changing Contexts and Conditions, London 2001.

ENQA Agency Review: Commission on Accreditation and Quality Assurance (CAQA), Brussels, 22 February 2018.

Giraoux H., The University in Chains: Confronting the Military-Industrial-Academic Complex, Boulder, CO 2007.

Grove J., "Serbian Political Figures Accused of plagiarising their PhDs", Times Higher Education Supplement, 24 July 2014, at <https://www.timeshighereducation.com/news/serbianpolitical-figures-accused-of-plagiarising-their-phds/2014668.article >.

Grušić U., Radeljić B., Tomić S., "Kako do doktorata? Lako! Slučaj ministra Stefanovića", Pešcanik, 1 June 2014, at <https://pescanik.net/kako-do-doktorata-lako-slucaj-ministrastefanovica/>.

41 H.H. Chng, “The Idea of the University: National Asset or Ivory Tower?", in A. Heijnen, R. van der Vaart (eds.), Places of Engagement. Reflections on Higher Education in 2040 - A Global Approach, Amsterdam 2018, p. 136. 
Karapandža R., "Velike tajne Malog majstora - Ili kako je Siniša Mali ukrao doktorat”, Peščanik, 9 July 2014, at <https://pescanik.net/velike-tajne-malog-majstora-ili-kako-je-sinisa-maliukrao-doktorat/>.

Liessmann K.P., Teorija neobrazovanosti. Zablude društva znanja, transl. by S. Muhamedagić, Zagreb 2008.

Lem S., His Master's Voice, transl. by M. Kandel, Kindle Edition, 2020.

Robinson M., “The Minister, His Mentor and the Fight against a Suspect System in Serbia”, Reuters, 23 June 2014, at <https://uk.reuters.com/article/uk-serbia-education-fraud/ the-minister-his-mentor-and-the-fight-against-a-suspect-system-in-serbia-idUKKBN0EY1EV20140623>.

Scott P., "Martin Trow's Elite-Mass-Universal Triptych: Conceptualising Higher Education Development", Higher Education Quarterly, vol. 73, no. 4 (2019), https://doi.org/10.1111/ hequ. 12224.

Šuvaković Z., "Serbia’s Degree Mills”, Al Jazeera Opinion, 25 July 2014, At <https://www.aljazeera.com/indepth/opinion/2014/07/serbia-degree-mills-2014725133314619696. html>.

Trow M., "Reflections on the Transition from Elite to Mass to Universal Access: Forms and Phases of Higher Education in Modern Societies since WWII", University of California, Berkeley, Institute of Governmental Studies, 2005, at <http://escholarship.org/uc/ item/96p3s213\#page-5>.

Trow M., "From Mass Higher Education to Universal Access: The American Advantage", University of California, Berkeley Research and Occasional Paper Series, CSHE.1.00 (2000), at <https://cshe.berkeley.edu/sites/default/files/publications/2000_from_mass_higher_education_to_universal_access_the_american_advantage.pdf $>$.

Trow M., "Problems in the Transition from Elite to Mass Higher Education", in Policies for Higher Education, Paris 1974.

Vögtle E.M., "20 years of Bologna - A Story of Success, a Story of Failure”, Innovation. The European Journal of Social Science Research, vol. 32, no. 4 (2019), https://doi.org/10.1080/13 511610.2019 .1594717$.

Wilkinson D., "Transforming the Social Order: The Role of the University in Social Change", Sociological Forum, vol. 9, no. 3 (1994), https://doi.org/10.1007/BF01466313.

Isidora JARIĆ - a sociologist, associate professor at the Department of Sociology, Faculty of Philosophy, University of Belgrade, where she teaches several courses relating to education and gender studies, on $\mathrm{BA}, \mathrm{MA}$ and $\mathrm{PhD}$ level. She is the author of two books (Parenthood under Risk: Socio-cultural Analysis of Stigmatizations of Rare Disease Patients, Faculty of Philosophy, Belgrade, 2017 and Hidden and Overt Curricula of High School Education in Sociology: Educational Reforms in Serbia (1960-2006), University of Belgrade, Faculty of Philosophy, Belgrade, 2014), the co-author of five, the editor of two, and author and co-author of more than 50 scientific papers. She is also the mother of nineteen-year-old Mane, a Red Ravens basketball player. 